\title{
IMPLEMENTASI KOMPETENSI MATA KULIAH PENDIDIKAN KEWARGANEGARAAN DI PERGURUAN TINGGI DALAM MENGHADAPI TANTANGAN GLOBALISASI
}

\author{
Febrian Alwan Bahrudin
}

\author{
Dosen Program Studi PPKn FKIP Universitas Sultan Ageng Tirtayasa \\ Serang, Indonesia \\ febrian_alwan24@yahoo.com
}

\begin{abstract}
This research contained about the implementation of civic education competency in college; in order to face the globalization defiance, this research has done at Sultan Ageng Tirtayasa University. The aim of this research is to know how the implementation of civic competency that consist of civic knowledge, civic skill, and civic disposition. This research used qualitative features with descriptive methode, the result of this research shows that the implementation of civic education competency in order to face the globalization defiance can be happened by three steps. The first step is planning, in planning step, the civic education supporting lecturer made a study planner for every semester together that customized with regular requisite book from directorate general and student affairs of Ministry of Research, Technology and Higher Education of the Republic of Indonesia. In arrangement of civic education learning in college has the competency that must accomplished by students and the implementation which in civic knowledge. Student got the knowledge from lecturer through the process teaching and learning in class about the materials that already made based on the study planner for each semester. After the first competency, next to the second one which is civic skill. For this compentency, students had given the activity that could build their critical thinking. Project citizen, one of the activity that given to students to reach their more knowledge potentions, especially their skill as student college. The last competency is civic disposition, this competency is the result of mixed two competencies; citizenship knowledge and citizenship skill. From citizenship character competency, in hopes that the students could get the knowledge and skill that shows a good personality based on Undang-Undang Dasar 1945, so they will not easily get contaminated by the negative impacts of globalization.
\end{abstract}

Keyword: Competency of Civic Education

\section{PENDAHULUAN}

Pendidikan merupakan salah satu indikator yang dapat menentukan kualitas suatu negara, ketika kuliatas pendidikan disuatu negara bagus, maka harapannya akan menjadi katagori negara yang maju, maka dari itu kualitas pendidikan haruslah diperhatikan utuk dapat mencetak kualitas sumberdaya manusia yang unggul yang dapat menopang terhadap kualitas suatu negara. kualitas pendidikan di negara Indonesia belumlah mencapai maksimal dalam kualitas pendidikannya, terlebih di era globalisasi ini banyak sekali tantangantantangan yang harus dihadapi untuk dapat terus meningkatkan kualiatas pendidikan.

Globalisasi merupakan suatu era keterbukaan dan ketergantungan antar setiap negara yang ada di dunia ini, yang seolah-olah tidak memiliki batasan antar negara satu dengan negara lainnya, salah satu perkembangan teknologi sebagai bentuk dari globalisasi itu sendiri memudahkan mendapatkan informasi yang begitu cepat dan luas, dan globalisasi juga 
menuntut untuk dapat berdaya saing dalam sekala internasional, maka peran pendidikan disinilah harus dapat dimaksimalkan untuk mendapatkan kualitas sumber daya manusia yang ungul untuk dapat menghadapi tantangan dari dunia internasional, pembeharuan dan peningkatan kualitas pendidikan di Indonesia selalu ditingkatkan tetapi belumlah mencapai maksimal, salah satu bentuk pembaharuan dan peningkatan tersebut dengan adanya perubahan kurikulum, tetapi perubahan kuriklum yang adapun dirasa masih belum maksimal untuk dapat meningkatkan kualitas yang berkaitan dengan pendidikan di Indonesia saat ini, selain kurikulum beberapa faktor yang mempengaruhi terhadap kualitas pendidikan di Indoneisa yaitu diantaranya, masih banyak ditemukan kualitas sarana prasana yang masih tidak memadai hal ini banyak sekali ditemukan dibeberapa tempat pendidikan yang lokasinya jauh dari pusat pemerintahan, sehingga kurangnya perhatian dari pemerintah itu sendiri, belum maksimalnya kualitas guru yang ada, hal ini dikarenakan masih banyaknya latar belakang keilmuan pendidikan yang tidak sesuai dengan kompetensi yang harus diberikan terhadap diri siswa, masih terdapatnya kesejahtraan tenaga pendidik yang masih minim hal ini terlihat dari banyaknya guru-guru honorer yang mendapatkan gaji yang sangat di bawah kebutuhan mereka, perestasi siswa yang masih kurang hal ini banyak ditemukan siswa yang cenderung sekolah hanya sebatas menggugurkan kewajiban saja untuk bersekolah tidak ingin lebih untuk mencapai prestasi yang ingin diraih, selain itu permasalahan-permasalahan lainya yaitu kesempatan pemerataan pendidikan belum berjalan dengan baik, ketidak sesuain dunia pendidikan dengan kebutuhan dunia kerja sehingga mengakibatnya banyaknya pengangguran, dan masih terdapat diberbagai sekolah atau perguruan tinggi yang bianya pendidikannya mahal sehingga banyak siswa atau calon mahasiswa yang ingin melajutkan pendidikan ke yang lebih tinggi terkendala oleh bianya, tetapi hal tersebut seharusnya harus segera diselesaiakan untuk dapat mencapai kualitas pendidikan yang lebih baik sehingga akan menghasilkan sumber daya manusia yang unggul dan berdaya saing internasional di tengah-tengah globalisasi saat ini. Berdasarkan permasalahanpermasalahn umum tersebut, khususnya perguruan tinggi sudah berusaha untuk dapat mengantisipasi pemasalahanpermasalahan di atas yaitu diantaranya dengan cara meningkatan kualitas sarana prasana yang ada, meningkatkan kualitas dosen baik melalui seminar maupun workshop, diharapkan dengan hal tersebut dalam poses perkuliahannya akan 
mencapai kompetensi yang menyeluruh atau maksimal dari mata kuliah yang dilaksanakannya. Kualitas pendidikan haruslah dapat mencapai target-target yang harus dicapai, dalam proses perkuliahan target tersebut adalah sasaran kompetensi dari mata kuliah itu sendiri, hal inipun berlaku untuk mata kuliah Pendidikan Kewarganegaraan, mata kuliah Penddikan Kewarganegaraan di perguruan tinggi salah satu mata kuliah wajib umum yang harus dikontak dan diikuti oleh seluruh mahasiswa khususnya pada tingakat pertama, mata kuliah ini dibeberapa perguruan tinggi di tempatkan di semester genap yaitu di semester dua hal ini berkalu juga di Universitas Sultan Ageng Tirtayasa yang menempatkan mata kuliah Pendidikan Kewarganegaraan di semester dua, tingkat pertama, tujuan dari mata kuliah ini salah satunya yaitu untuk dapat mengembangkan kepribadian mahasiswa yang sesuai dengan nilia-nilai Pancasila dan UUD 1945 sebagai perwujuadan warga negara yang baik (good citizen) di Indonesia, untuk dapat mengembangkan kepribadian mahasiswa bukanlah hal yang mudah terlebih di era sekarang, di era globalisasi banyak sekali tantangantantangan yang harus dihadapi terutama dari dampak negatif globalisasi, dan disinilah peran dari mata kuliah Pendidikan Kewarganegaraan haruslah dimaksimalkan untuk dapat menanggulangi dampak-dampak negatif globalisasi terhadap diri mahasiswa. Dampak-dampak negatif yang dapat ditimbulkan dari globalisasi terhadap suatu negara yang berkaitan dengan nasionalisme diantaranya yaitu tidak adanya rasa cita tanah air sehingga hanya mementingkan kepentingan pribadinya saja, tidak adanya rasa rela berkorban yang akhirnya muncul rasa egois, hilangnya rasa persatuan dan kesatuan dan hilangnya rasa pantang menyerah. Berdasarkan hal tersebut di atas dampak negatif yang terjadi di negara ini diantaranya banyaknya oknum-oknum pelaku kejahatan yang melakukan tindak pidana korupsi, tindak pidana pinipuan, penyalah gunaan obatobatan terlarang, dan tindakan-tidakan yang bertentangan dengan hukum lainnya, dan hal ini merupakan contoh yang buruk untuk penerus generasi muda atau mahasiswa kedepannya, maka dari itu eksistensi dan peran dari mata kuliah Pendidikan Kewarganegaraan haruslah dimaksimalkan untuk dapat menanggulangi hal tersebut.

Peran dari mata kuliah Pendidikan Kewarganegaraan di ruang lingkup perguruan tinggi masih dianggap belumlah maksimal untuk dapat menanggulangi dampak-dampak negatif dari arus globalisasi, hal ini dilatar belakangi oleh durasi waktu yang cenderung terbatas hanya pada satu semester saja sebayak 
enam belas kali petemuan termasuk di pertemuan ke delapan dilaksanakan ujian tengah semester dan di pertemuan terakhir yaitu ke enam belas dilaksanakan ujian akhir semseter, sehingga kompetensi utamanya berkaitan implementasi tidaklah dapat semaksimal mungkin tercapai, dan seharusnya nilai-nilai mata kuliah Pendidikan Kewarganegaraan harus tetap dikembangkan terhadap diri mahasiswa, tidak terbatas oleh kontrak perkuliahan dan durasi waktu yang ditempuh, hal ini bertujuan untuk dapat menanggulangi halhal yang muncul dari dampak negatif globalisasi yang terus berjalan terhadap diri mahasiswa, globalisasi bukan hanya berdampak terhadap negara Indonesia saja, tetapi berdampak juga untuk seluruh negara yang ada di dunia ini, baik yang berdampak positif, maupun yang berdampak negatif dari gelobalisasi itu sendiri, maka salah satu cara yaitu melalui jalur pendidikan mengantisipasi dampak negatif globalisasi, negara-negara yang ada di dunia ini mengajarkan melalui pola-pola pendidikan folmal seperti mata pelajaran atau mata kuliah Pendidikan Kewarganegaraan, walaupun di berbagai negara nama dari Pendidikan Kewarganegaraan itu sendiri berbedabeda, ada yang menamakan civic education, citizenship education, atau ada yang menamakannya juga democracy education, dan dengan istilah-istilah nama lainnya, mata kuliah ini diharapkan dapat menjadikan mahasiswa menjadi mahasiswa yang memilki kompetensi yang unggul dalam hal kecerdasan, mampu bertanggung jawab, dan memiliki karakter yang baik sesuai dengan nilai-nilai Pancasila dan UUD 1945 sebagai perwujudan warga negara yang baik di Indonesia.

Di negara Indonesia mata kuliah Pendidikan Kewarganegaraan merupakan bagian dari mata kuliah wajib umum yang harus dilaksanakan di perguruan tinggi baik perguruan tinggi negeri ataupun swasta, hal ini sebagaimana terdapat dalam Undang-Undang nomor 12 tahun 2012 yang menyatkan bahwa "pendidikan tinggi memerlukan suatu pendidikan yang dapat mengambangkan ilmu pengetahuan dan teknologi, dan menghasilkan intelektual, ilmuan, dan/atau professional yang berbudaya, kreatif, toleran, demokratis, berkarakter tangguh, serta berani membela kebenaran untuk kepentingan bangsa". selajutnya terdapat dalam isi pasal 35 ayat 2 menyatakan bahwa "kurikulum pendidikan tinggi merupakan pedoman penyelenggaraan kegiatan pembelajaran untuk mencapai tujuan pendidikan tinggi wajib memuat mata kuliah, Agama, Pancasila, Kewarganegaraan, dan Bahasa Indonesia, yang dilaksanakan melalui kegiatan kurikuler, kokulikurer, dan ekstrakurikuler". 
Pernyataan di atas dapat tarik kesimpulan bahwa peran dari Pendidikan Kewarganegaraan sangatlah penting hal ini dkarenakan mata kuliah Pendidikan Kewarganegaraan merupakan salah satu meta kuliah wajib umum yang memilki tujuan untuk dapat membentuk warga negara yang baik, dan mampu menjadi pribadi cerdas, berbudaya, toleransi, demoratis, berkarakter tangguh serta bisa diandalkan untuk kepentingan bangsa dan negara, Pendidikan Kewarganegaraan merupakan bagian dari bentuk bela negara, diharapkan dengan adanya Pendidikan Kewarganegaraan dalam ruang lingkup perguruan tinggi, diharapkan mahasiswa dapat memahami konsep kenegaraan yang ada di Indonesia, sekaligus memilki rasa nasionalisme dan patriotisme ditengahtengah tantangan arus negatif globalisasi, pendapat lain berkaitan dengan tujuan Pendidikan Kewarganegraan dikemukakan oleh Winataputra (2014) yang menyatakan bahwa: "dari sudut pandang holistik Pendidikan Kewarganegaraan memilki tujuan yaitu setiap warga negara Indonesia (young citizens) dapat memilki rasa kebangsaan setra cita tanah air yang sesuai dengan nilai dan moral Pancasila, nilai dan norma Undang-Undang Dasar Negara Republik Indonesia Tahun 1945, nilai dan kebhinneka tunggal ika, serta memilki komitmen bernegara terhadap negara kesatuan republik Indonesia". apabila ditarik suatu kesimpulan dari pernyataan tersebut bahwa Pendidikan Kewarganegaraan diharapkan memilki rasa kebangsaan dan cinta tanah air yang kuat terhadap negara republik Indonesia, yang dilandasi oleh nilai-nilai yang sesuai dengan Pancasila dan Undang-Undang Dasar 1945, selain itu yang mempertegas tentang pentingnya Pendidikan Kewarganegaraan adalah terdapat dalam Undang-Undang No. 20 Tahun 2003 tentang sistem pendidikan nasional yang menyatakan bahwa "Pendidikan Kewarganegaraan bertujuan untuk dapat membentuk peserta didik menjadi manusia atau warga negara yang memilki rasa kebangsaan dan cinta tanah air". selain hal penjelaasan di atas mata pelajaran atau mata kuliah Pendidikan Kewarganegaraan juga memiliki kompetensi yang harus dicapai dalam proses perkuliahan yaitu sebagaimana dikemukakan oleh Margaret Stimman Branson (1999:8) yang menjelaskan bahwa "Pendidikan Kewarganegaraan memilki kompetensi yang dibagi menjadi tiga bagian yaitu pengetahuan kewarganegaraan (civic knowledge), keterampilan kewarganegaraan (civic skill) dan karakter kewarganegaraan (civic disposition)" berdasarkan pendapat tersebut bahawa dalam ruang lingkup ketiga kompetensi tersubut yaitu pengetahuan kewarganegaraan (civic knowledge) dalam 
ruang lingkup kompetensi ini merupakan pengetahuan yang harus dimiliki mahasiswa tentang pengetahuan ruang lingkup kenegaraan, selanjutnya yaitu keterampilan kewarganegaraan (civic skill) yaitu merupakan keterampilan yang harus dimiliki mahasiswa yang terdiri dari keterampilan intelektual dan keterampilan berpartisipasi, dan yang terakhir adalah karakter kewarganegaraan (civic disposition) yaitu merupakan karakter yang baik yang harus ada dalam diri mahasiswa yang terdiri dari karakter privat dan publik yang sekaligus dapat mencerminkan sebagai karakter yang sesuai dengan nilai-nilai Pancasila dan Undang-Undang Dasar 1945. Dengan tujuan dan kompetensi Pendidikan Kewarganegaraan tersebut diharapkan dapat menanggulangi dampak negetif dari globalisasi terhadap bangsa ini terutama mahasiswa yang bagian dari generasi muda penurus bangsa.

Berdasarkan hal tersebut di atas penulis tertarik untuk dapat mendeskripsikan bagaimana implementasi kompetensi mata kuliah Pendidikan Kewarganegaraan di Universitas Sultan Ageng Tirtanyasa dalam menghadapi tantangan globalisasi.

\section{METODE PENELITIAN}

Penggunaan pendekatan penelitian dimaksudkan untuk dapat menentukan cara-cara ataupun langkah-langkah yang harus dilaksakan oleh peneliti berdasarkan pengetahuan yang sesuai dengan hasil temuan penelitian. Penggunaan dalam penelitian ini menggunakan pendekatan kualitatif, pendekatan penelitian kualitatif ini sebagaimana dikemukakan oleh Lexy J. Moleong (2005:6) yang terdapat dalam buku metode pendekatan kualitatif menyatakan bahwa "penelitian kualitatif adalah penelitian yang bermaksud untuk dapat memahami fenomena tentang apa yang dialami oleh subjek penelitian, misalnya, prilaku, persepsi, tindakan, secara holistik dan dengan cara deskriptif'. Berdasarkan hal tersebut dapat diambil suatu kesimpulan bahwa pendekatan penelitian dengan menggunakan jenis pendekatan yang bersifat kualitatif adalah suatu jenis pendekatan penelitian yang menekankan pada aspek kejadian yang dialami subjek penelitian itu sendiri. Pemilihan pendekatan kualitatif ini didasarkan atas dasar yaitu diantaranya, penelitian ini membutuhkan data lapangan yang bersifat aktual serta kontekstual, selain itu pemilihan pendekatan ini juga didasari oleh bagaimana keterkaitan permasalahan yang diteliti berdasarkan data-data primer dari subjek penelitian yang dilakukan.

Selain penggunaan penelitian dalam penelitain ini peneliti juga menggunakan metode penelitian, penggunaan motode penelitian bertujuan untuk dapat 
mungumpulkan data, menyusun data, dan menganalisis data, yang berdasarkan kajian pemasalahan yang peneliti lakukan. Hal ini sebagaimana dikemukakan oleh Suharsimi Arikunto (2006:160) yang menyatakan bahwa "cara yang digunakan peneliti untuk mengumpulkan data penelitian" Bersarkan hal tersebut peneliti berusaha mengumpulkan data-data penelitian untuk dapat dianalisa berdasarkan hasil dari penelitian itu sendiri. Penggunaan metode dalam penelitian ini yaitu menggunakan metode deskripstif, penggunaan metode deskriptif sendiri dalam penelitian ini ingin menggambarkan atau menjelaskan faktafakta atau keadaan yang berkaiatan dengan hasil penelitian yang telah dilakukan oleh peneliti, yaitu berkaitan dengan implementasi kompetensi mata kuliah Pendidikan Kewarganegaraan di perguruan tinggi dalam menghadapi tantangan globalisasi.

\section{HASIL PENELITIAN DAN PEMBAHASAN}

\section{HASIL PENELITIAN}

Implementasi kompetensi mata kuliah Pendidikan Kewarganegaraan di Universitas Sultan Ageng Tirtanyasa dilaksanakan sesuai dengan langakahlangkah yang telah dibuat yaitu melalui tahap perencanaan, pelaksanaan, dan evaluasi, dalam tahap perencanaan pembelajaran atau perkuliahan yaitu dosen mata kuliah pengembangan kepribadian dalam bidang ilmu mata kuliah Pendidikan Kewarganegaraan membuat Rencana Pembelajaran Semester (RPS) yang disusun bersama-sama dan disetujui oleh koordinator mata kuliah pengembangan kepribadian bidang ilmu mata kuliah Pendidikan Kewarganegaraan, pembuatan rencana pembelajaran semester (RPS) itu sendiri disesuaikan dengan buku ajar mata kuliah wajib umum Direktorat Jendral Pembelajaran dan Kemahasiswaan Kementrian Riset, Teknologi dan Pendidikan Tinggi Republik Indonesia, Tujuan dibuatnya rencana pembelajaran semester (RPS) ini adalah sebagai panduan sasaran materi dan kompetensi yang harus diajarkan oleh dosen terhadap mahasiswa, selain itu dibuatnya rancana pembelajaran semester (RPS) ini juga untuk dapat menyeragamkan kompetensi mata kuliah Pendidikan Kewaraganegaran di semua jurusan ataupun prodi yang ada di Universitas Sultan Ageng Tirtanyasa sehingga semua sasaran kompetensinya dapat tercapai dan tidak ada perbedaan satu sama lain.

Dosen pengempu mata kuliah Pendidikan Kewarganegaraan yang ada di Universitas Sultan Ageng Tirtanya merupakan dosendosen yang professional dibidang keilmuannya, dengan latar belakang pendidikan yang sesuai untuk dapat 
mengajar mata kuliah Pendidikan Kewarganegaraan, selain itu melalui lembaga pengembangan pendidikan dan penjamin mutu (LP3M) yang ada di Universitas Sultan Ageng Tirtayasa dosendosen mata kuliah pengembangan kepribadia (MPK) sering melakukan kegiatan-kegiatan seperti seminar ataupun workshop hal ini bertujuan untuk dapat meningkatkan kompetensi dosen pengempu mata kuliah pengembangan kepribadian, sehingga kompetensi yang dicapai mahasiswapun akan lebih baik lagi. Dosen-dosen mata kuliah pengembangan kepribadian itu sendiri terdiri dari dosen mata kuliah Pendidikan Pancasila, Pendidikan Agama, Pendidikan Bahasa Indonesia, dan termasuk dosen Pendidikan Kewarganegaraan, hal tersebut sesuai ketentuan yang ada dalam UndangUndang no.12 tahun 2012 tentang pendidikan tinggi "diperlukan pendidikan yang mampu mengembangkan ilmu pengetahuan dan teknologi serta menghasilkan itelektual, ilmuan, dan atau professional yang berbudaya dan kereatif, toleran, demokratis, berkarakter tangguh, serta berani membela kebenaran untuk kepentingan bangsa", hal ini juga sesuai dengan ketentuan dalam pasal 35 ayat 2 yang menyatakan bahwa "pendidikan tinggi merupakan pedoman penyelenggaraan kegiatan pembelajaran, untuk dapat mencapai tujuan pendidikan tinggi wajib memuat mata kuliah, Agama, Pancasila, Kewarganegaraan, Bahasa Indonesia, yang dilaksanakan melalui kurikuler, kokurikuler, dan ekstrakurikuler".

Berdasarkan Undang-Undang no 12 tahun 2012 serta dalam pasal 35 ayat 2, Unversitas Sultan Ageng Tirtayata melalui lembaga pengembangan pendidikan dan penjamin mutu (LP3M) yang diketuai koordinator pusat mata kuliah pengembangan keperibadian mempersiapkan dosen-dosen yang memiliki kompetensi dan professional dibidangnya untuk dapat mengampu mata kuliah pengembangan kepribadian termasuk didalamnya dosen-dosen pengempu mata kuliah Pendidikan Kewarganegaraan sehingga diharapkan dengan adanya dosen-dosen yang memiliki kompetensi dan professional dibidangnya akan mengahasilan proses pembelajaran atau perkuliahan yang terlaksana dengan baik dan pada akhirnya menghasilkan mahasiswa yang memilki kompetensi yang unggul dalam bidang mata kuliah Pendidikan Kewarganegaraan.

Tahapa perencanaan sesuai dengan penjelasan di atas dimaksudkan untuk dapat mempersipakan tahap lanjutan yaitu pada tahap pelaksaan pembelajaran atau pun perkuliahan, ketika tahap perencanaan terlaksana dengan baik maka diharapkan akan menghasilkan hasil yang baik pula 
dalam proses pembelajaran ataupun perkuliahan, sehingga sasaran kompetensi yang harus didapat mahasiswa akan berjalan dengan baik, setelah tahap perencanaan, tahapan selajutnya yaitu tahapan pelaksanaan pembelajaran mata kuliah Pendidikan Kewarganegaraan, dalam tahapan ini secara kompetensi mata kuliah Pendidikan Kewarganegaraan terdiri dari tiga bagian yaitu pengetahuan kewarganegaraan (civic knowledge), keterampilan kewarganegaraan (civic skill) dan karakter kewarganegaraan (civic disposition) dan dalam ketiga kompetensi tersebut haruslah dapat dicapai dalam proses perkuliahan Pendidikan Kewarganegaraan.

\section{PEMBAHASAN}

\section{Pengetahuan Kewarganegaraan} (Civic Knowledge)

Implementasi kompetensi yang pertama berkaitan dengan pengetahuan kewarganegaraan (civic knowledge) dosen mengajarkan materi-materi mata kuliah Pendidikan Kewarganegaraan sesuai dengan rancana pembelajaran semester (RPS) yang telah dibuat pada tahap perencanaan pembelajaran, materi-materi yang diajarkan dalam proses perkuliahan termasuk ke dalam pengetahuan kewarganegaraan (civic knowledge) materi-materi tersebut terdiri dari materi yang membahas tentang hakikat Pendidikan Kewarganegraan di perguruan tinggi, identitas nasional, integrasi nasional, konstitusi, kewajiban dan hak warga negara, demokrasi, penegakan hukum, wawasan nusantara, ketahanan nasional, dan tugas mahasiswa berupa project citizen. Materi-materi di atas dijarkan oleh dosen terhadap diri mahasiswa dalam proses perkuliahan sebayak enam belas kali pertemuan dalam satu semester termasuk ujian tengah semester di pertemuan ke delapan, dan ujian akhir semester di pertemuan ke enam belas, deharapkan dengan materi-materi yang diajarkan tersebut mahasiswa dapat mengetahui dan memahami bagaimana menjadi pribadi yang berpengetahuan tentang kenegaraan di negara Indonesia, hal ini didasarkan atas kompetensi yang pertama yaitu pengetahuan kewarganegraan atau dikenal juga sebagai civic knowledge, dengen pengetahuan kewarganegaraan ini diharapkan mahasiswa dapat mengetahui tentang bagaimana cerminan sebagai good citizen atau warga negara yang baik di Indonesia yang sesuai dengan Pancasila dan Undang-Undang Dasar 1945. Materimateri yang diajarkan akan memberikan pengetahuan dalam diri mahasiswa sehingga mahasiswa akan 
mendapatkan pengetahuan sekaligus untuk dapat menanggulangi dari dampak-dampak negatif globalisasi yang tidak sesuai dengan nilai-nilai Pancasila dan Undang-Undang Dasar 1945, dampak negatif globalisasi yang terjadi saat ini terjadi diberbagai bidang yaitu diantaranya dampak negatif globalisasi dalam bidang ekonomi, dampak negatif globalisasi dalam bidang politik, dampak negatif globalisasi dalam bidang sosial budanya, dampak negatif dalam bidang teknologi dan informasi, dan dampak negatif globalisasi dalam bidang lainnya, sampai termasuk dampak negatif globalisasi dalam bidang pendidikan, selain itu dalam proses perkuliahan Pendidikan Kewarganegaraan, dosen mendisain proses perkuliahan dengan menentukan pendekatan pembelajaran, strategi pembelajaran, metode pembelajaran, maupun teknik pembelajaran, hal tersebut dilakukan untuk dapat menggali potensi dalam diri mahasiswa dalam segi pengetahuan mahasiswa tentang pengetahuan kewarganegaraan, sehingga ranah kognitif dalam diri mahasiswa akan lebih dapat dimaksimalkan, dengan adanya mata kuliah Pendidikan Kewarganegaraan, diharapkan dampak negatif dari globalisasi tersebut dapat dirubah untuk mendapatkan pengaruh ataupun dampak yang positif dari globalisasi tersebut, sehingga akan berdampak meninggkatkan kualitas sumberdaya manusia yang unggul melalui pendidikan itu sendiri, ketika kualitas pendidikannya bagus maka diharapkan dapat mengahasilkan sumberdaya manusia yang bagus pula dan hal tersebutpun akan menepoang terhadap kemajuan suatu bangsa dan negara, negara-negara yang memiliki kualitas pendidikan yang bagus, banyak sekali yang mengedepankan pendidikan yang berbasis karakter salah satunya yaitu melalui Pendidikan Kewarganegaraan, walaupun berbedabeda nama dari Pendidikan Kewarganegaraan di berbagai negara, tetapi pada intinya bahwa Pendidikan Kewarganegaraan disetiap negara memerlukan

Pendidikan Kewarganegaraan termasuk di Indonesia sebagai pembelajaran yang mengajarkan bagaimana menjadi sosok warga negara yang baik, yang tidak terkontaminasi oleh dampak-dampak negatif globalisasi.

\section{Keterampilan Kewarganegaraan (Civic Skill)}

Kompetensi selanjutnya setalah pengetahuan kewarganegaraan atau dikenal juga sebagai civic knowledge 
yaitu kompetensi keterampilan kewarganegaraan atau civic skill, proses pembelajaran atapun perkuliahan Pendidikan Kewarganegaraan yang banyak orang menganggap bahwa hanya berorientasi pada pengetahuan saja atau civic knowledge yang hanya sebatas mata kuliah hafalan saja mulai pudar perlahan-lahan dengan langkah selanjutnya kompetensi yang diterapkan yaitu civic skill atau keterampilan kewarganegaraan, dalam kompetensi ini merupakan tindak lanjut dari kompetensi yang pertama, setelah mahasiswa mendapatkan pengetahuan tentang materi-materi yang telah diajarakan, mahasiswa diharapakan dapat terampil dalam menjalankan pengetahuan kewarganegaraaan yang telah didapatkan atau juga bagian dari ranah psikomotor, keterampilaan ini tercermin dalam diri mahasiswa dengan cara bagaimana mahasiswa dapat mengatasi permasalahanpermasalahan yang terdapat di bangsa dan negara ini. dalam keterampilan kewarganegaraan terdapat beberapa indikator yaitu diantaranya intellectual skill (keterampilan intelektual) keterampian ini dimaksudkan untuk dapat mengembangkan mahasiswa yang berbawasan luas, efektif serta bertanggung jawab melalui dengan cara berpikir keritis, dalam tahap ini yaitu melalui beberapa keterampilan diantaranya mengeidentifkasi dan mendeskripsikan, menjelaskan dan menganalisis, mengevaluasi sampai pada tahap menentuan sikap, berdasarkan tahapan-tahapan tersebut mahasiswa dapat memilah mana dampak positif mana yang negatif dari globalisasi saat ini, indikator selanjutnya yaitu participation skill (keterampilan berpartisipasi), dalam indikator keterampilan ini mahasiswa diharapkan dapat berperan serta untuk dapat mencari solusi segala permasalahan-permasalahan yang berkaitan dengan dampak negatif globalisasi terhadap bangsa ini, keterampilan kewarganegaran atau civic skill ini sendiri juga mengarahkan mahasiswa untuk dapat terampil dan berpartisipasi dalam berkehidupan berbangsa dan bernegara.

\section{Karakter Kewarganegaraan (Civic} Disposition)

Kompetensi selanjutnya yaitu adalah kompetensi karakter kewarganegaraan atau dikenal juaga sebagai civic disposition, dalam kompetensi ini merupakan tindak lanjut dari kedua kompotensi sebelumnya, karakter kewarganegaraan yang ingin dicapai 
dalam kompetensi ini adalah karakter yang sesuai dengan nilai-nilai Pancasila dan Undang-Undang Dasar 1945 sebagai cerminan warga negara yang baik di Indonesia. setelah mahasiswa dibekali dengan pengetahuan materi yang diajarkan dalam proses perkuliah, dan sekaligus dapat terampil menampilkan memecahkan permasalahan yang berkaitan dengan materi yang dibahas, pada akhirnya mahasiswa diharapkan memiki karakter sebagai cerminan mahasiswa yang memiliki karakter yang baik. Pengembangan karakter yang baik dalam diri mahasiswa tidak terbatas dilaksanakan dalam proses pembelajaran di dalam kelas saja, tetapi juga di inplementasikan di luar kelas dengan cara mencerminkan kepribadian yang baik dalam ruang lingkup universitas ataupun di luar universitas. Dalam karakter kewarganegaraan itu sendiri terdiri dari dua indikator yang pertama yaitu berkaitan dengan karakter privat (pribadi) dan karakter publik (kemasyarakatan), dalam karakter yang pertama yang berkaitan dengan karakter privat mahasiswa diharapkan dapat memilki kepribadian yang mencerminkan pribadi yang memiki intelektual yang baik, prilaku yang baik, selanjutnya dalam karakter publik mahasiswa diharapkan dapat mencerminkan memiliki keperibadian yang memilki kepedulian mangatasi segala macam permasalahanpermasalahan yang ada di bangsa dan negara ini. Pada tahap selanjutnya untuk dapat menguatkan kompetensikompetensi dalam mata kuliah Pendidikan Kewarganegaraan mahasiswa ditugaskan untuk dapat membuat project citizen, project citizen ini dimaksudkan untuk dapat mengimplemtasikan kompetensi yang telah dicapai dalam bentuk pelaporan tugas penelitaian project citizen, project citizen itu sendiri merupakan model pembelajaran yang pertama kali digunakan di Amerika Serikat, pada tahun 1992 yang akhirnya dikembangkan menjadi program nasional yaitu oleh center for civic education, project citizen merupakan pola pembelajaran dalam bentuk tugas yang harus dilakukan siswa atau mahasiswa yang mengedepankan instructional treatment yang berbasis masalah dengan tujuan mengimplentasikan komptensi Pendidikan Kewarganegaraan. Dalam proses project citizen tugas dosen sebagai instruktur dan fasilitator terhadap diri mahasiswa untuk mendapatkan informasi dan arahan berkaitan tema yang diteliti, dalam 
penelitian ini semua mahasiswa dituntut berperan serta aktif dalam melakukan penelitian sehinga kompetensi dari semua kompetensi Pendidikan Kewaraganegaraan dapat dimaksimalkan mulai dari segi pengetahuan, keterampilan dan karakter itu sendiri. Langkah-langkah yang dilakukan dalam project citizen terdiri dari beberapa tahapan yaitu diantaranya mahasiswa mengidentifikasi permasalahanpermasalahan yang ada di negara ini, dalam tahap ini dilakukan secara berkelompok, selanjutnya kelompok tersebut melakukan pengamatan, wawancara, dan juga dokumentasi, setelah data didapatkan maka langkah selanjutnya yaitu menentukan topik masalah sebagai fokus kajian, setelah itu mahasiswa melalui kelompoknya masing-masing mengumpulkan informasi terkait fokus kajian yang ingin diteliti, mengembangkan portofolio kelas, pada tahap selanjutnya yaitu mahasiswa mengadakan penyajian portofolio dalam kegiatan simulasi dengar pendapat, langkah terakhir yaitu melaksanakan kajian berdasarkan pengalaman belajar yang telah dilakukan.

Model pembelajaran project citizen ini sangat cocok digunakan dalam mata kuliah Pendidikan Kewarganegaraan sebagai bentuk dari implementasi keseluruhan kompetensi mata kuliah itu sendiri terutama berkaitan dengan civic skill, dan project citizen inipun bisa digunakan bagaimana menanggulangi permasalahanpermasalahan dari dampak negatif globalisasi. Dampak negatif globalsasi bisa diteliti melalui project citzen yaitu dengan cara bagaimana dampak negatif globalisasi terhadap diri mahasiswa sebagai generasi penerus bangsa, menentukan fokus masalah berkaitan dengan dampak globalisasi, mencari dan mengumpulkan informasi berkaitan dengan dampak negatif globalisasi, mengembangkan pelaporan berkaiatan dengan project citizen yang berkaitan dengan dampak globalisasi, setelah itu disajikannya hasil penelitan, dan yang terakhir mahasiswa dapat melakukan kajian terhadap dampak negatif dari globalisasi terhadap diri mahasiswa. Berdasarkan kompetensikompetensi Pendidikan Kewaraganegaraan di atas merupakan sasaran mata kuliah pengembangan kepribadian dalam mengembangkan kemempuan pengetahuan, kemampuan keterampilan, dan dapat mencerminkan kepribadian yang baik dalam diri mahasiswa atau di kenal juga sebagai perwujudan warga negara Indonesia 
yang mencerminkan kepribadian yang baik atau good citizen di Indonesia, diharapakan dengan perwujudan sebagai warga negara Indonesia yang memilki karakter yang baik, atau mahasiswa yang baik dapat memilahmilih mana dampak positif globalisasi yang harus diamabil dan mana dampak negatif globalisasi yang harus ditinggalkan. Setelah pada tahap perencanaan dan tahap pelaksanaan selesai dilakukan maka tahap selanjutnya adalah tahap akhir yaitu evaluasi dalam tahap evaluasi ini dosen selaku pengampu mata kuliah pengembangan kepribadian mengevaluasi hasil dari perkuliahan yanga telah dilakukan dengan berdasarkan tiga indikator Pendidikan Kewarganegaraan, yaitu yang pertama adalah pengetahuan kewaraganegraan (civic knowledge) dalam ranah pengetahuan ini ditemukan beberapa mahasiswa yang masih memiliki keinginan belajar yang masih kurang, dan ketika proses pembelajaran masih terdapat mahasiswa yang hanya sebatas mengandalkan penjelasan dari dosen, sehingga perlunya bagaimana dosen lebih berperan aktif dalam membangkitkan semangat belajar mahasiswa tersebut melalui beberapa teknik ataupun pendekatan pembelajaran yang pada akhirnya dapat meningkatkan motivasi belajar mahasiswawa tersebut, kendala selanjutnya dalam keterampilan kewarganegaraan (civic skill), yaitu masih ditemukannya beberapa mahasiswa yang mengerjakan tugastugas dalam bentuk penyelesaian masalah ataupun mengerjakan proect citizen hanya sebatas ikut mengerjakan saja sihingga daya keritis mahasiswa terhadap aspek tugas penelitian berkaitan dengan project citizen tidak dapat menghasilkan daya kritis yang kuat dalam memecahakan suatu permasalahan dalam bentuk tugas project citizen tersebut, dan yang terakhir yaitu berkaitan dengan kompetensi karakter kewarganegaraan (civic disposition) kompetensi ini merupakan sebagai muara dari kedua kompetensi sebelumnya yaitu pengetahuan kewarganegaraan dan keterampilan kewarganegaraan, diharapakan setelah mendapatkan kompetensi sebelumnya dalam diri mahasiswa melekat karakter kewarganegaraan tetapi masih terdapat beberapa mahasiswa yang belum maksimal dalam menanggulangi dampak negatif dari globalisasi, tetapi secara keseluruhan kompetensi yang dicapai dalam matakuliah Pendidikan Kewarganegaraan dapat mengembangkan kompetensi 
mahasiswa baik dari segi pengetahuan kewarganegaraan yang diditerima oleh mahasiswa, dari segi keterampilan yang diterima mahasiswa, dan dari segi karakter yang melekat dalam diri mahasiswa hal ini sesuai dengan sasaran kompetensi mata kuliah Pendidikan Kewaraganegaraan sebagai mata kuliah pengembangan kepribadian.

\section{SIMPULAN}

Berdasarkan hasil pembahasan penelitian yang telah peneliti lakukan dapat diambil kesimpulan bahwa implementasi kompetensi mata kuliah Pendidikan Kewarganegaraan yang ada di Universitas Sultan Ageng Tirtanyasa dalam menghadapi tantangan globalisasi sudah berjalan dengan baik hal ini dikarenakan proses perkuliah Pendidikan Kewaraganegaraan mengedepankan kualitas perkuliahan itu sendiri, proses perkuliahan itu dimulai dari tahap perencanaan dalam tahap ini proses yang dilakukan yaitu terdiri dari kegiatan dosen dalam membuat rancana pembelajaran semester (RPS) yang dibuat sesacara bersama-sama oleh seluruh dosen pengampu mata kuliah pengembangan kepribadian dalam bidang ilmu Pendidikan Kewarganegaraan yang disesuaikan dengan buku ajar mata kuliah wajib umum direktorat jendral pembelajaran dan kemahasiswaan kementrian riset, teknologi dan pendidikan tinggi republik Indonesia, hal in dimaksudkan untuk dapat menyeragamkan sasaran kompetensi mata kuliah yang diajarkan untuk mahasiswa di semua jurusan atau prodi yang ada di Universitas Sultan Ageng Tirtayasa, selain pembuatan RPS dosen-dosen Pendidikan Kewarganegaraan juga sering melakukan kegiatan seperti seminar ataupun workshop yang berkaitan dengan mata kuliah Pendidikan Kewarganegaraan dalam ruang lingkup matakuliah pengembangan kepribadian yang dilaksanakan melalui lembaga pengembangan pendidikan dan penjamin mutu (LP3M) yang ada di Universitas Sultan Ageng Tirtayasa, hal tersebut dimaksudkan untuk dapat meningkatkan kualitas mutu dan profesionalisme dosen Pendidikan Kewaraganegaraan sehingga diharapakan akan meningkatkan kualitas proses perkuliahan yang pada akhirnya akan menghasilkan kompetensi yang lebih baik terhadap diri mahasiswa itu sendiri. Dalam tahap pelaksanaan proses perkuliahan yang berlangsung mengedepankan tiga aspek kompetensi mata kuliah Pendidikan Kewarganegaraan yaitu terdiri dari segi pengetahuan kewarganegaraan (civic knowledge), segi keterampilan kewarganegaraan (civic skill) dan dari segi karakter kewarganegaraan (civic disposition), dalam pelaksanaanya 
atau implementasinya yang berkaitan dengan pengetahuan kewarganegaraan (civic knowledge) mahasiswa diajarkan tentang materi-materi perkuliahan yang berdasarkan rancana pembelajaran semester (RPS) yang telah dibuat sehingga mahasiswa mendapatkan pengetahuan dan memahami materi yang diajarkan, setelah ranah pengetahuan kewarganegaraan didapatkan mahasiswa, dosen mata kuliah Pendidikan Kewarganegaraanpun harus dapat mengembangkan kompetensi yang kedua yaitu keterampilan kewarganegaraan (civic skill), dalam kompetensi keterampilan kewarganegaraan dosen mengarahkan mahasiswa untuk dapat membuat project citzen sebagai bentuk daya analisa mahasiswa mengali suatu permasalahan berkaiatan dengan permasalahanpermasahan yang ada di negara ini, sampai pada akhirnya dapat menemukan solusi dari permasalahan tersebut, hal ini dimaksudkan untuk dapat mengembangkan daya keritis dan kreatif mahasiswa terhadap suatu kajian permasalahan yang pada akhirnya harus menemukan solusi dari permasalahan tersebut, dan yang terakhir kompetensi karakter kewarganegaraan (civic disposition) kompetensi ini merupakan muara dari kedua kompetensi sebelumnya, dalam kompetensi ini ranah yang ingin dicapai adalah bagaimana mahasiswa dapat memilki karakter yang baik yang seseuai dengan nilai-nilai Pancasila dan Undang-Undang Dasar 1945, ketika mahasiwa sudah dapat menerapkan karakter yang baik yang sesuai dengan nilai-nilai Pancasila dan Undang-Undang Dasar 1945 maka diharapankan mahasiswa dapat menghindari dampak negatif globalisasi dan dan dapat mengambil dampak positif dari globalisasi, point terakhir dari tahap perkuliahan adalah tahap evaluasi dalam tahap ini dosen Pendidikan Kewaraganegaraan melakukan evaluasi terhadap diri mahasiswa dengan indikator penilaian berdasarkan kompetensi Pendidikan Kewarganegaraan, diharapkan dengan adanya evalusi tersebut dosen Pendidikan Kewarganegaran dapat terus meningkatkan kualiatas perkuliahan, sehinga akan menghasilkan mahasiswamahasiswa yang memiki kompetensi Pendidikan Kewarganegaraan yang lebih baik lagi sebagai bentuk implementasinya mahasiswa memilki pengetahuan yang luas dari segi pengetahuan kewarganegaraan, memilki daya keritis dan solusi yang baik untuk dapat membangun kemajuan negara, dan point terakhir dapat mencerminkan karakter yang baik yang sesuai dengan Pancasila dan Undang-Undang dasar 1945.

Berdasarkan kesimpulan di atas perlu kiranya kualiatas pekuliahan yang sudah berlangsung harus terus ditingkatkan 
dengan cara melakukan inovasi-inovasi dalam proses perkuliahan sehingga dengan adanya inovasi tersebut dapat meningkatkan kualiatas dalam segi komptensi Pendidikan Kewarganegaraan, terlebih di era revolusi industri 4.0 saat ini yang menentut pembeharuan kearah yang lebih baik, dan diharapkan dengan adanya project citizen bukan hanya sekedar penelitan yang harus dilakukan buat mahasiswa tetapi diharapkan dapat memberikan kontribusi perbaikan kearah yang lebih baik, saran-saran tersebut kiranya akan lebih meninggkatkan kualiatas proses perkuliahan yang pada akhirnya mahasiswa akan lebih memilki kompetensi yang lebih baik lagi.

\section{DAFTAR PUSTAKA}

\section{Buku}

Arikunto, Suharsimi. 2006. Prosedur

Penelitian Suatu Pendekatan

Praktik.

Jakarta: Rineka Cipta.

Branson, S Margaret. 1999. Belajar Civic

Education dari Amerika.

Yogyakarta:

Lkis.

Budimansyah, Dasim, 2002. Model

Pembelajaran dan Penilaian Berbasis Portofolio. Bandung: PT. Ganesindo.
Lexy J. Moleong. 2005. Metodologi

Penelitian Kualitatif, Bandung:

Remaja Rosdakarya.

Winataputra, U.S. (2014). Diskursus Aktual

Tentang Paradigma Pendidikan

Kewarganegaraan (PKn) Dalam

Konteks Kurikulum 2013. Bahan

Diskusi dalam Semnas PKnAP3KnI.

\section{Perundang-Undangan}

Undang-Undang Dasar 1945.

Undang-Undang Republik Indonesia Nomor.

14 Tahun 2005 tentang Guru dan Dosen.

Undang-Undang Republik Indonesia Nomor.

20 Tahun 2003 tentang Sistem

Pendidikan Nasional.

Undang-Undang Republik Indonesia

Nomor. 12 Tahun 2012 tentang

Pendidikan Tinggi.

\section{Jurnal}

Sutiyono, Suharno. (2018). Revormasi

Pendidikan Pancasila dan

Kewarganegaraan untuk

Menguatkan Nasionalisme Warga

Negara Muda di Wilayah

Perbatasan. Jurnal Pancasila dan

Kewarganegaraan. Vol 6, No.1, 1-

16. 